\title{
DESIGN FOR TWO-FLUID FINE NOZZLE WITH 50\% FILL RATIO
}

\author{
Norzelawati ASMUIN ${ }^{1, \text { a }}$ \\ ${ }^{1}$ Centre for Energy and Industrial Environment Study (CEIES), \\ Faculty of Mechanical and Manufacturing Engineering, Universiti Tun Hussein \\ Onn Malaysia, 86400 Parit Raja, Batu Pahat, Johor, Malaysia \\ anorzela@uthm.edu.my
}

Keyword : aerosol atomiser, two-fluid fine nozzle, fill ratio, droplet size.

Abstract. Sufficient air insert by reduced liquid in flashing propellants are required to produce fine droplet size with symmetrical spray in an aerosol atomiser without swirling design. It is called novel matched valve-actuator with two-fluid fine nozzle. Two-fluid fine nozzle design is an arrangement between air-assist atomiser insert, air blast and effervescent atomiser insert. However, $50 \%$ fill ratio and 9bar on pressure can with a currently acceptable become "Benchmark Objective" in this research. The results shows a few measurement with the same volume flow rate and variable flow rate of two fluids atomiser which have been taken in the experimental. $50 \mathrm{ml} / \mathrm{min}$ for liquid flow rate and $150 \mathrm{ml} / \mathrm{min}$ flow rate of insert gas could reduce droplet size less than $70 \mu \mathrm{m}$ SMD by modifying the insert to promote greater cone angle and droplet size distribution with differences on quantity of air, liquid supply and the atomising velocity. Validation of two-fluid fine nozzle results is also recommended to be carried out and compared with the experiment results which related to turbulence kinetic energy with the atomiser insert and droplet size.

\subsection{Introduction}

The experimental apparatus was designed to investigate a variety of two-fluid fine nozzle designs using flow board, which could independently control both gas and liquid to the atomiser designs. Compressed air and water was used and the following data were acquired. The atomiser designs were tested for droplet size, mass flow rate for liquid and gas with different pressure.

\subsection{Literature Review}

Two-fluid fine nozzle design is an arrangement between air-assist atomiser insert, air blast and effervescent atomiser insert. Air-assist atomiser inserts and air blast has similar function, the only differences are on quantity of air supply and the atomising velocity. Air-assist is injecting air which supports the disintegration process of liquid jet or sheet, while air blast vastly used in high pressure such as combustion systems and gas turbines: (Lefebvre, 1989), (Solomon, 1985). While the effervescent process is a flashing of dissolved, gas and create bubbly flow inside the atomiser insert. Effervescent is the process of various actively introducing gas bubbles into a liquid flow, immediately upstream of the exit orifice, thereby forming a two-phase flow. These are of interest due to their potential for using a small flow of atomising gas to produce a very fine spray (Swithenbank, 2001), (Catlin and Swithenbank, 2001). Researchers and engineers have studied their use for application including Household Aerosols, (Kuta et. al, 2003), (Bush, 2003). The technique has not been applied in commercial aerosols because even at the low value of Gas/Liquid mass Ratio (GLR) used (around 1\%), can pressures will drops too quickly if using the compresses gas in the can to atomise. Also dispensing the gas and liquid simultaneously and producing the required flow, is too complex. In addition, effervescent atomising prediction for modelling drop size was recently made by researchers on high viscosity material such as gelatinized starch suspension (Burby, 2005). These three concepts (air-assist atomiser insert, air blast and effervescent atomiser insert) were implemented in two-fluid fine nozzle which used 'liquid and gas' arrangement. This was delivered by injecting gas in the liquid stream in order to create and maintain the bubbly flow and hence achieve good atomisation and sprays via the atomiser insert. In this research, 
characteristics of two-fluid fine nozzle are divided into two categories. Aerosol swirl atomiser insert using gas injection and aerosol plain atomiser insert with gas injection.

\subsection{Methodology}

In conventional "VPT" (Vapour Pressure Tapping) can, gas is introduced from the can via the tube. The atomisation is poor if such inserts are incorporated because the present aerosol valves have convoluted passages which cause gas to collect into relatively large bubbles which deter good atomisation. It is necessary to design new aerosol valves in order to obtain good atomisation. The aim is to maintain an ideal homogeneous fine bubble mixture at the exit of the valve which is the optimum inlet condition for the two-fluid fine nozzle. The combination of new valve and novel twophase atomising insert can be considered as a single system, (N.Asmuin, 2014). This device is thus a combination of a novel aerosol valve and matched novel insert. An average liquid flow rate $\mathrm{Q}_{\text {liq }}$ is assumed, and an average atomising gas flow rate $\mathrm{Q}_{\text {gas }}$ is assumed, where the gas is bled from the can during spraying as shown in Figure 3.1 below.

\subsection{Fill Ratio}

As shown in Figure 3.1, the Fill Ratio F (\%) is defined as

$$
\mathrm{F}=100 \mathrm{Vliq} / \text { Vcan }=100 \mathrm{Vliq} /(\mathrm{Vgas}+\text { Vliq })
$$

The value of $\mathrm{F}$ can be chosen by the manufacturer. The initial can pressure P1 can also be chosen, being limited according to the type of can. The pressure P2 when the can has just been emptied of all liquid must be at least a certain value, in order that acceptable spraying occurs as the can is emptying, this depends upon the atomiser design. It is important to recall that the gas volume used for atomising is calculated at atmospheric conditions (STP or ATP).

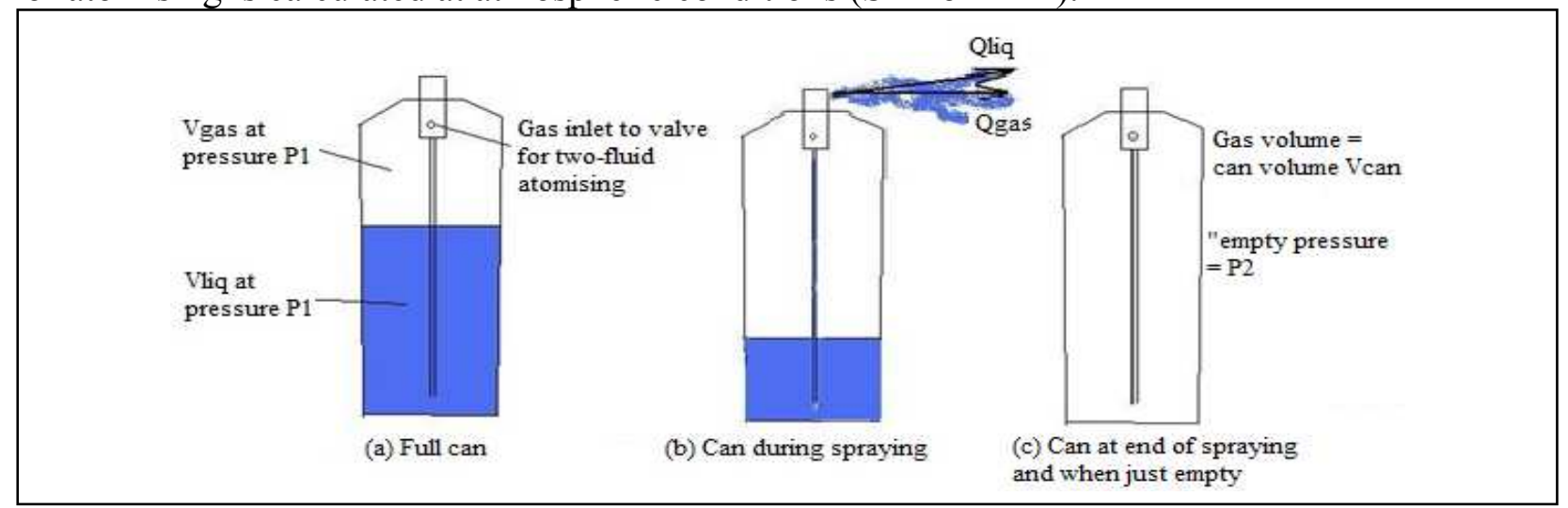

Figure 3.1: A can (a)when full, (b)during spraying, and (c)when empty of liquid, (N.Asmuin, 2011, 2014).

The initial gas volume in the can, Vgas, is defined at the initial gas pressure P1 (gauge), if it were at atmospheric pressure, it will interpret as Vgas $((\mathrm{P} 1+1) / 1)$. When the can has just been emptied of liquid, atmospheric pressure become $\operatorname{Vcan}((\mathrm{P} 2+1) / 1)$. So the volume of gas, at atmospheric pressure, that has been bled off for atomising is

$$
\text { - } \quad \text { Vatom }=\operatorname{Vgas}(\mathrm{P} 1+1)-\operatorname{Vcan}(\mathrm{P} 2+1)
$$

- $\quad$ Where Vcan $=$ Vgas + Vliq

- By dividing both sides of (2) by Vliq and using (3.1) to substitute for Vgas in (3.2), will get:

$$
\text { Vatom/Vliq }=((100-\mathrm{F}) / \mathrm{F})(\mathrm{P} 1+1)-(100 / \mathrm{F})(\mathrm{P} 2+1)
$$

- Ratio of total volumes sprayed is exactly the same as ratio of gas and liquid volume flow rates.

$$
\text { Qgas/Qliq = Vatom/Vliq }
$$

From (3.3) and (3.4), calculation for fill ratio can be made with the available average atomising gas/liquid volume flow ratio for different initial fill ratio and can pressure, $\mathrm{F}$ and $\mathrm{P} 1$, and the final can pressure P2: see examples in the Table 3.1. Manufacturers/consumer product companies, are not keen on reducing fill ratio below $50 \%$, nor on using the higher pressure 12 bar cans: however doing either of these would greatly reduce design challenges and ensure better spraying through can 
life. Minimizing the pressure value P2 at which the insert still atomises well, is seen to be very important. At present the atomiser designs are probably at good condition for a 12 bar can with $40 \%$ fill, with final pressure around 3.5bar: Legally and technically good, but not ideal for companies.

Table 3.1: Fill ratio for liquid and gas, (N.Asmuin, 2011, 2014).

\begin{tabular}{|l|l|l|l|l|l|}
\hline $\begin{array}{l}\text { Case } \\
\text { Number }\end{array}$ & $\begin{array}{l}\text { Fill } \\
\text { Ratio } \\
\text { F \% }\end{array}$ & $\begin{array}{l}\text { Initial Can } \\
\text { Pressure P1 } \\
\text { Bar (gauge) }\end{array}$ & $\begin{array}{l}\text { Final Can } \\
\text { Pressure P2 } \\
\text { Bar (gauge) }\end{array}$ & $\begin{array}{l}\text { Available } \\
\text { Qgas/Qliq for } \\
\text { atomizing } \\
\text { (calculated) }\end{array}$ & Notes \\
\hline 1 & 40 & 9.0 & 2.5 & 6.25 & $\begin{array}{l}\text { Represents a "9bar can" and with lower fill } \\
\text { ratio than currently normal }\end{array}$ \\
\hline 2 & 50 & 9.0 & 2.5 & 3.0 & $\begin{array}{l}\text { A 9bar can with a currently acceptable Fill } \\
\text { Ratio "Benchmark Objective" }\end{array}$ \\
\hline 4 & 40 & 9.0 & 3.5 & 3.75 & $\begin{array}{l}\text { For 40\% fill, increasing the required value for } \\
\text { P2 reduces the available gas/liquid atomising } \\
\text { ratio c.f(1) }\end{array}$ \\
\hline 5 & 50 & 9.0 & 3.5 & $\begin{array}{l}\text { Increasing the required value for P2 with } \\
50 \% \text { fill, results in a much too small } \\
\text { gas/liquid ratio for atomising }\end{array}$ \\
\hline
\end{tabular}

Simple form of plain atomiser was shown in Figure 3.2 shows illustration diagram of set-up for atomiser testing for two-fluid atomisation. It also shows the water and gas in two-fluid atomisation goes through on different inlet. It can be categories into (1)input pressure for gas, (2)input pressure for liquid, (3)mixing chamber, (4) internal geometry and (5)ratio between orifice length and orifice diameter $\left(1_{\mathrm{o}} / \mathrm{d}_{\mathrm{o}}\right)$.

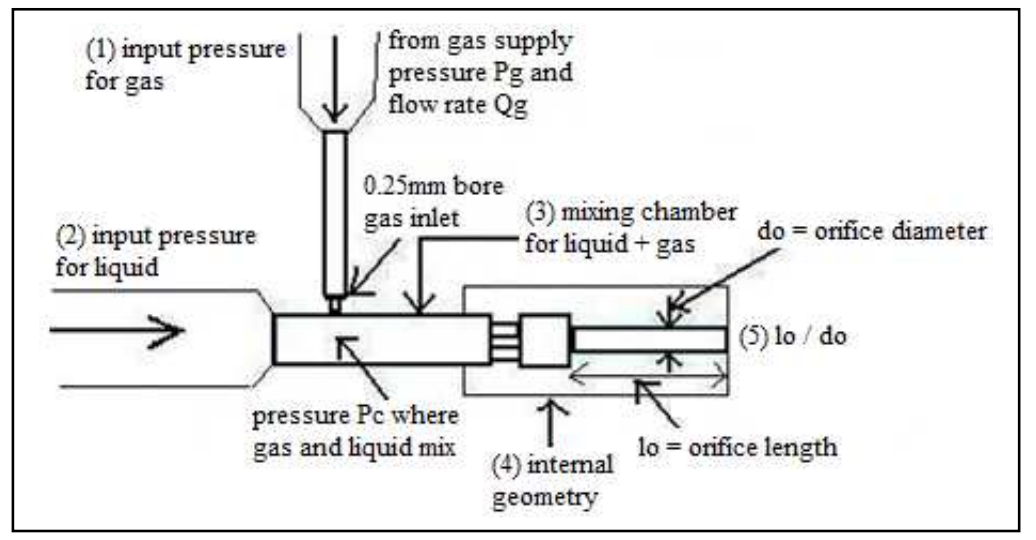

Figure 3.2: Illustration diagram of set-up for atomiser testing for two-fluid atomisation, (N.Asmuin, 2011, 2014).

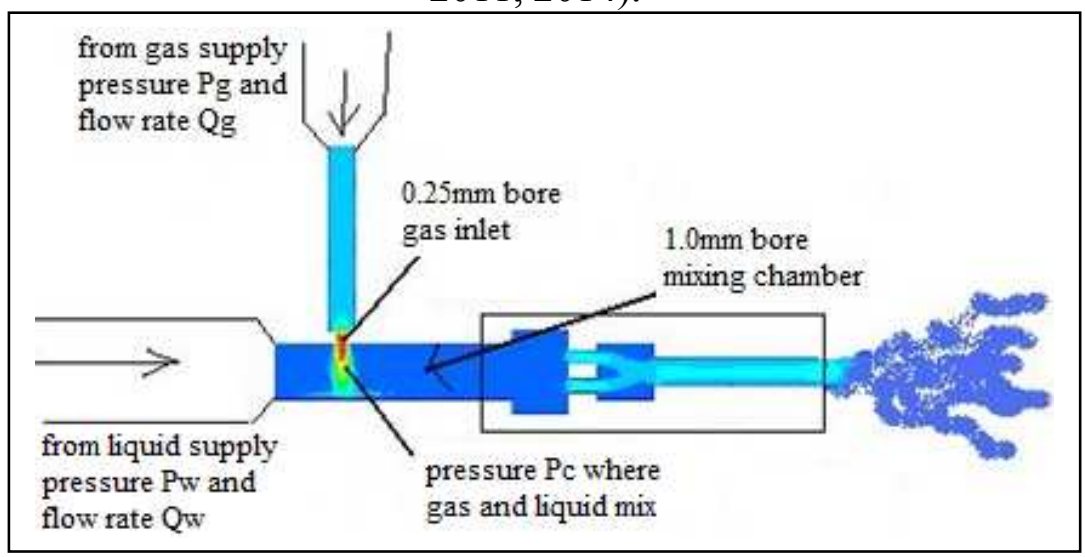

Figure 3.3: Schematic of set-up for atomiser testing, (N.Asmuin, 2011, 2014). 


\subsection{Two-Fluid Fine Nozzle Design with Simulateass Can}

The test has concentrated on using the two-fluid fine nozzle in a way which controls and measures the flow rates of the liquid and of the atomising gas as shown in Figure 3.3. These pressure values are similar but not exactly the same, as they have been varied using the control board in order to get the required flow rates. The process of "Two-Fluid Fine Nozzle Design with Simulated Brass Can as shown in Figure 3.4 was constructed similar to an aerosol can and was used to replace the pressure vessel.

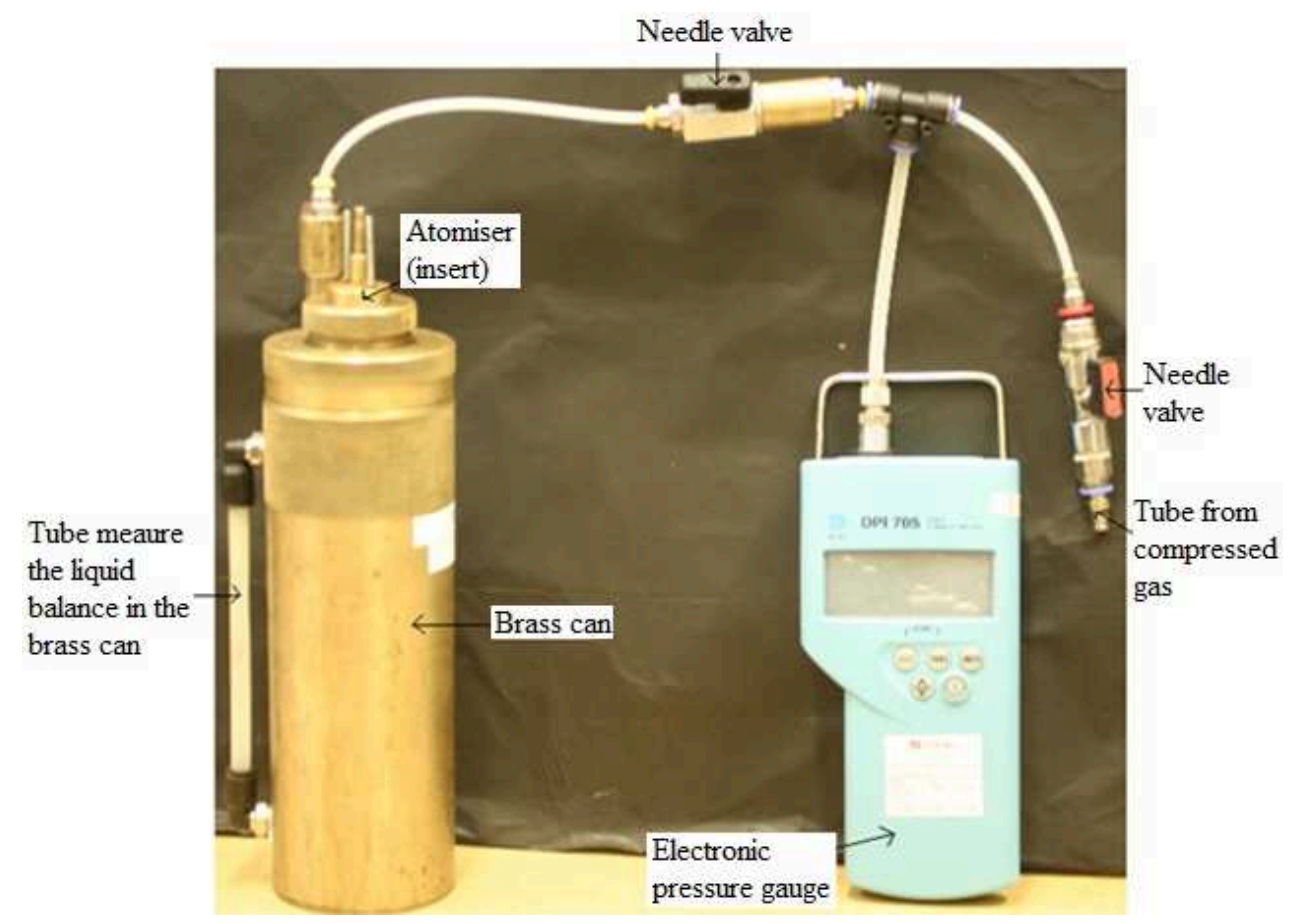

Figure 3.4: Brass can assembled for experiment, (N.Asmuin, 2011).

Water was put into the brass can to achieve $50 \%$ fill ratio is 238 millilitres (full volume is 476 millilitres). The brass can was assembled with atomiser insert (as shown in Figure 3.2), valves, mixing chamber and sealed and checked to ensure that there was no leaks. Compressed air was used to pressurise the brass can up to 9 bars. Two needle valves were used in this experiment. The first needle valve was connected between the compressed air and pressure gauge, for controlling the pressure insert to the brass can. The second, needle valve was connected between the pressure gauge to brass can. This provided pressure measurement inside the brass can to be taken the lifetime of the spray.

\subsection{Result and Discussion}

These atomisers operated at a number of liquid and air injection pressure. Table 3.2 shows result for three different types of two-fluid fine nozzle. It also shows that the experiment with different atomiser on two fluids needs different input pressure from compressed air. Therefore, the bigger pressure input the smaller drop size distribution will atomised. Table 3.3 shows the effect varying three different parameters: atomiser design, liquid injection and flow rate. The lower flow rate for water and gas can only run under low pressure. Low flow rate with low pressure produced big droplet size. Different atomiser design with different flow rate and pressure give different drop size distribution.

\subsection{Conclusion}

Three concepts of two-fluid fine nozzle with air-assist atomiser insert, air blast and effervescent atomiser insert were implemented, which used 'liquid and gas' arrangement. Aerosol plain atomiser insert was delivered by injecting gas is the best characteristics of two-fluid fine nozzle. It was 
shown in Figure 3.2, where the complication of bubbly flow must pass through the valve before reaching the insert. For this reason the orifices in the valve stem should have as large an area as possible so that the valve has minimum effect on the bubble flow and its pressure drop. The valve that was used in the two-fluid fine nozzle is a "low loss valve", which sometimes produces a core at the centre of the spray. The droplet size could be reduced less than $70 \mu \mathrm{m}$ SMD by modifying the insert to promote greater cone angle and droplet distribution as shown in aerosol plain atomiser insert with gas injection data. Further validation of the CFD multiphase flow ("two-fluid atomisation") results is also recommended to be carried out and compared with the experiment results.

Table 3.2: The same volume flow rate of two fluids atomiser: (N.Asmuin, 2011, 2014).

\begin{tabular}{|c|c|c|c|c|c|c|c|c|}
\hline $\begin{array}{l}\text { No. } \\
\text { By } \\
\text { week }\end{array}$ & $\begin{array}{l}\text { Run } \\
\text { no. }\end{array}$ & Atomiser & Part at atomiser & $\begin{array}{l}\text { Water } \\
\text { pressure } \\
P w \text { (bar) }\end{array}$ & $\begin{array}{l}\text { Gas } \\
\text { pressure } P g(\text { bar })\end{array}$ & $\begin{array}{l}Q w(\mathrm{ml} / \mathrm{min}) \\
\text { measured }\end{array}$ & $\begin{array}{l}Q g \\
(\mathrm{ml} / \mathrm{min}) \\
\text { measured }\end{array}$ & $\begin{array}{l}\text { SMD } \\
(\mu \mathrm{m})\end{array}$ \\
\hline 10.9 & 1 & DV001_woC3DE $+\mathrm{C} 1+\mathrm{E} 7$ & $\mathrm{~A}+\mathrm{B}+\mathrm{C} 1+\mathrm{E} 7$ & 5.8 & 5.89 & 50 & 150 & 47.75 \\
\hline 10.10 & 2 & DV001_woC3DE_+C1+E7 & $\mathrm{A}+\mathrm{B}+\mathrm{C} 1+\mathrm{E} 7$ & 8.75 & 8.82 & 50 & 150 & 40.24 \\
\hline 10.18 & 1 & DV001_woC3E_+E3 & $\mathrm{A}+\mathrm{B}+\mathrm{D}+\mathrm{E} 3$ & 6.87 & 6.94 & 50 & 150 & 54.79 \\
\hline 10.19 & 2 & DV001_woC3E_+E3 & $\mathrm{A}+\mathrm{B}+\mathrm{D}+\mathrm{E} 3$ & 7.8 & 7.93 & 50 & 150 & 47.62 \\
\hline 11.8 & 1 & DV001 woC3 $+\mathrm{C} 1+\mathrm{A} 02$ & $\mathrm{~A}+\mathrm{B}+\mathrm{C} 1+\mathrm{D}+\mathrm{E}+\mathrm{A} 02$ & 6.46 & 6.54 & 50 & 150 & 53.88 \\
\hline 11.9 & 2 & DV001_woC3_+C1+A02 & $\mathrm{A}+\mathrm{B}+\mathrm{C} 1+\mathrm{D}+\mathrm{E}+\mathrm{A} 02$ & 6.58 & 6.66 & 50 & 150 & 54.40 \\
\hline
\end{tabular}

Table 3.3: The variable flow rate of two fluids atomiser: (N.Asmuin, 2011, 2014).

\begin{tabular}{|c|c|c|c|c|c|c|c|c|}
\hline $\begin{array}{l}\text { No. } \\
\text { By } \\
\text { week }\end{array}$ & $\begin{array}{l}\text { Run } \\
\text { no. }\end{array}$ & Atomiser & Part at atomiser & $\begin{array}{l}\text { Water } \\
\text { pressure } \\
P w \text { (bar) }\end{array}$ & $\begin{array}{l}\text { Gas } \\
\text { pressure } P g \text { (bar) }\end{array}$ & $\begin{array}{l}Q w(\mathrm{ml} / \mathrm{min}) \\
\text { Measured }\end{array}$ & $\begin{array}{l}Q g(\mathrm{ml} / \mathrm{min}) \\
\text { measured }\end{array}$ & $\begin{array}{l}\mathrm{SM} \\
(\mu \mathrm{m})\end{array}$ \\
\hline 10.7 & 1 & DV001_woC3DE_+C1+E7 & $\mathrm{A}+\mathrm{B}+\mathrm{C} 1+\mathrm{E} 7$ & 1.37 & 1.4 & 20 & 60 & 264.7 \\
\hline 10.8 & 2 & DV001_woC3DE_+C1+E7 & $\mathrm{A}+\mathrm{B}+\mathrm{C} 1+\mathrm{E} 7$ & 2.4 & 2.52 & 30 & 90 & 101.5 \\
\hline 10.9 & 3 & DV001_woC3DE_+C1+E7 & $\mathrm{A}+\mathrm{B}+\mathrm{C} 1+\mathrm{E} 7$ & 5.8 & 5.89 & 50 & 150 & 47.75 \\
\hline 10.10 & 4 & DV001_woC3DE_+C1+E7 & $\mathrm{A}+\mathrm{B}+\mathrm{C} 1+\mathrm{E} 7$ & 8.75 & 8.82 & 50 & 150 & 40.24 \\
\hline 10.16 & 1 & DV001_woC3E_+E3 & $\mathrm{A}+\mathrm{B}+\mathrm{D}+\mathrm{E} 3$ & 1.2 & 1.29 & 20 & 60 & 230.73 \\
\hline 10.17 & 2 & DV001_woC3E_+E3 & $\mathrm{A}+\mathrm{B}+\mathrm{D}+\mathrm{E} 3$ & 2.2 & 2.32 & 30 & 90 & 130.61 \\
\hline 10.18 & 3 & DV001_woC3E_+E3 & $\mathrm{A}+\mathrm{B}+\mathrm{D}+\mathrm{E} 3$ & 6.87 & 6.94 & 50 & 150 & 54.79 \\
\hline 10.19 & 4 & DV001_woC3E_+E3 & $\mathrm{A}+\mathrm{B}+\mathrm{D}+\mathrm{E} 3$ & 7.8 & 7.93 & 50 & 150 & 47.62 \\
\hline 11.6 & 1 & DV001_woC3_+C1+A02 & $\mathrm{A}+\mathrm{B}+\mathrm{C} 1+\mathrm{D}+\mathrm{E}+\mathrm{A} 02$ & 0.87 & 0.91 & 20 & 60 & 241.7 \\
\hline 11.7 & 2 & DV001_woC3_+C1+A02 & $\mathrm{A}+\mathrm{B}+\mathrm{C} 1+\mathrm{D}+\mathrm{E}+\mathrm{A} 02$ & 2.27 & 2.31 & 30 & 90 & 144.1 \\
\hline 11.8 & 3 & DV001_woC3 + $+\mathrm{C} 1+\mathrm{A} 02$ & $\mathrm{~A}+\mathrm{B}+\mathrm{C} 1+\mathrm{D}+\mathrm{E}+\mathrm{A} 02$ & 6.46 & 6.54 & 50 & 150 & 53.88 \\
\hline 11.9 & 4 & DV001_woC3_+C1+A02 & $\mathrm{A}+\mathrm{B}+\mathrm{C} 1+\mathrm{D}+\mathrm{E}+\mathrm{A} 02$ & 6.58 & 6.66 & 50 & 150 & 54.40 \\
\hline
\end{tabular}

\section{References}

[1] Burby, M.L., The Design and Evaluation of Variable Fuel-placement Airblast Atomizers, PhD Thesis, University of Manchester, August 2005.

[2] Bush, S.G. and Sojka, P.E., Entrainment by conventional effervescent sprays, Atom. And Sprays, 13, 605, 2003.

[3] Catlin, C.A. and Swithenbank, J., Physical processes influencing effervescent atomizer performance in the slug and annular flow regimes, Atomization and Sprays, 11, 575, 2001.

[4] Kuta, T.J., Plesniak, M.W. and Sojka, P.E., Entrainment control for ligament controlled effervescent atomizer sprays, Atom. and Sprays, by 13, 561, 2003.

[5] Lefebvre, A.H., Atomization and Sprays, Hemisphere Publishing Corporation, USA, 1989. 
[6] N. Asmuin, 'Investigation into Novel Matched Valve-Actuator Atomiser Insert Design for Compressed Gas Aerosol', PhD Thesis, Salford University, UK, 2011.

[7] Solomon, A.S.P., Flow and Atomization in Flashing Injectors, Atomisation and Spray Technology 1, pg. 53-76, 1985.

[8] Swithenbank, J., Characterization and evaluation of a CFD model of effervescent atomization, Swithenbank J., GR/L74460/01, 2001

[9] N.Asmuin, Investigation Novel Matched Valve-Actuator With Atomiser Inserts Design For Two-Fluid With 50\% Fill Rati, Proceedings of the 2014 International Conference on Industrial Engineering and Operations Management, IEOM 2014, January 7 - 9,2014. 